\title{
Effect of Feeding Some Evergreen Tropical Browse Plant Leaf on Blood Parameters of Growing Rabbits
}

\author{
Okwori Abel Ibrahim, Abejeshi Ikienilase Margaret, Shaahu David Terhemba
}

Department of Animal Production, College of Animal Science, University of Agriculture Makurdi, Nigeria

\section{Email address:}

abelokwori@yahoo.com (O. A. Ibrahim), abejeshilkienilase@yahoo.com (A. I. Margaret), dtshaahu@gmail.com (S. D. Terhemba)

\section{To cite this article:}

Okwori Abel Ibrahim, Abejeshi Ikienilase Margaret, Shaahu David Terhemba. Effect of Feeding Some Evergreen Tropical Browse Plant Leaf on Blood Parameters of Growing Rabbits. International Journal of Applied Agricultural Sciences. Vol. 3, No. 4, 2017 , pp. $92-98$. doi: $10.11648 /$ j.ijaas.20170304.12

Received: March 30, 2017; Accepted: July 13, 2017; Published: July 25, 2017

\begin{abstract}
A feeding trial was conducted with thirty (30) weaner rabbits to investigate the nutritive potentials of some evergreen tropical browse plants leaves (Ficcus thoningii, Vitex doniana, Daniela oliveri, Sarcocephalus latifolia). Thirty mixed breed rabbits were used and randomly assigned to five (5) treatments $\left(\mathrm{T}_{1}-\mathrm{T}_{5}\right)$. The rabbits on Treatment 1 diet were fed concentrate only (control), while those in $\mathrm{T}_{2}-\mathrm{T}_{5}$ were fed as follows; Ficcus thoningii + concentrate of $3 \%$ weekly body weight, Vitex doniana + concentrate of $3 \%$ weekly body weight, Daniela oliveri + concentrate of 3\% weekly body weight, and Sarcocephalus latifolia + concentrate of 3\% weekly body weight, respectively. Results of preliminary (analytical) experiments showed that the browse plants contained DE which ranged from 2722.77 to $3180.25 \mathrm{kcal}$, CP from 8.70 to $17.47 \%$, Crude Fibre from 7.32 to $22.08 \%$. The rabbits were fed and given drinking water ad-libitum for the twelve-week experimental duration during which their haematology and serum biochemical indices were evaluated. Of the haematological parameters, significant $(\mathrm{P}<0.05)$ differences were observed on Mean corpuscular volume which varied from 65.03 to $81.40 \times 10^{15} / \mathrm{fl}$, while there were no differences $(\mathrm{P}>0.05)$ on other haematological parameters. However, the values were not far from the normal reference values. The diet also had significant $(\mathrm{P}<0.05)$ effects on serum biochemical indices such as Total protein which values ranged from $4.17 \mathrm{~b}$ to $6.37 \mathrm{mg} / \mathrm{dl}$ and glucose from $77.6-100.10 \mathrm{mg} / \mathrm{dl}$. However, these values were similar with the normal reference values.
\end{abstract}

Keywords: Browse Plant, Haematology, Rabbits, Serum Biochemical Indices

\section{Introduction}

That recent studies on the potential of plant leaves as diet for livestock have shown significant growth responses by animals fed such leaves. Such leaves have been shown to yield relatively higher levels of crude protein and mineral and lower crude fibre level than tropical grasses and are gaining acceptance as feedstuff in livestock diet and are considered to be non-conventional feeding materials. This has brought a growing realization in the use of plant leaves as diet for livestock. The nutrient profile of these nonconventional feeding materials compares favourably well with some conventional feeding materials [3]. There is need therefore to search for locally cheap sources of feed that are readily available particularly those that do not attract competition in consumption between humans and livestock but have direct relevance in human food channel [2].
George [18] stated that even though the bulk of their weight is water, leafy vegetable represents a veritable natural pharmacy of minerals, vitamins and phytochemicals. He concluded that the potassium content of leafy vegetables is good in the control of diuretic and hypertensive complication in animals because it lowers arterial blood pressure. Vegetable like Ficcus thoningii, Vitex doniana, Daniela oliveri, Sarcocephalus latifolia are important sources of protective foods which are highly beneficial for the maintenance of good health and prevention of diseases [18].

Animal protein contains the essential amino acids which are more balanced and readily available to meet human nutritional needs than plant protein [12].

Rabbit production has a considerable potential in developing countries in alleviating the low animal protein intake for the supply of the much needed protein due to the low capital investment and space requirement, short 
generation intervals, rapid growth rate, high reproductive potential and ability to utilize the abundant browse plant leaves and other fibrous materials $[12,8]$.

In spite of these advantages, rabbit production has not received, the desired attention in the tropics. Productivity is usually $50 \%$ or less of what is typical in the temperate countries [12]. While high temperature (Causing heat stress and discomfort) may have contributed to the low productivity [13], Rabbit farming in Nigeria is relatively new but it has the potential of making significant contribution to the country meat supply. It involves a low input, low cost system and offers a very profitable small scale background production due to its size, efficiency and simplicity of management (39). The study was conducted, to investigate the nutritive potentials of some evergreen tropical browse plant leaves (Ficcus thoningii, Vitex doniana, Daniela oliveri, Sarcocephalus latifolia) on blood parameters of rabbits.

\section{Materials and Methods}

\subsection{Experimental Site}

The experiment was carried out at the Teaching and Research Farm of the Federal College of Education Obudu, Cross River State. The Farm is located at the Department of Agriculture site Obanliku. Obanliku is located in the Northernmost part of Cross River State, with height of $74.5 \mathrm{~m}$ above sea level, between longitude $6^{\circ} 37^{\prime}$ "North and latitude $9^{\circ} 13$ " East within the Tropical Savannah region of Nigeria [31], [22]. It is characterized by two distinct seasons, the wet season and the dry season. The wet season starts from early April to early November while the dry season starts from middle November to March. The area is warm with ambient temperature range between $20.5^{\circ} \mathrm{C}$ to $30.7^{\circ} \mathrm{C}$ having an annual rainfall of about $4300 \mathrm{~mm}$ to $4500 \mathrm{~mm}$. Relative humidity ranges between 57\% in February/March and 89\% in August/September.

\subsection{Source of the Browse Plant Leaves}

Sarcocephalus latifolia, Vitex doniana and Daniela oliveri were all harvested along the College Farm road while Ficcus thoningii was harvested from villages surrounding the Farm.

\subsection{Experimental Diets}

The Experimental browse plant leaves were harvested and wilted over night to reduce moisture content, weighed and fed fresh each morning to the experimental animals. The experimental animals were provided with concentrate corresponding to $3 \%$ of their weekly body weight. The animals were fed their various browse plant leaves ad libitum throughout the experimental period of twelve weeks. The left over feed was collected and weighed each morning before the supply of the new browse plant leaves and concentrate, the experimental Treatments were represented as follows.

Treatment 1: concentrate only (control)

Treatment 2: Ficcus thoningii + concentrate of 3\% weekly body weight
Treatment 3: Vitex doniana + concentrate of $3 \%$ weekly body weight

Treatment 4: Daniela oliveri + concentrate of 3\% weekly body weight

Treatment 5: Sarcocephalus Latifolia + concentrate of 3\% weekly body weight.

Experimental diet was formulated as shown in table 1.

Table 1. Ingredient and Nutrient Composition of concentrate diets (\%).

\begin{tabular}{ll}
\hline Ingredient & \% Inclusion \\
\hline Maize & 46.79 \\
Rice offal & 22.90 \\
Full fat soyabean & 19.07 \\
Groundnut cake & 9.53 \\
Bone ash & 2.00 \\
Common salt & 0.25 \\
premix & 0.25 \\
Methionine & 0.10 \\
Lysine & 0.10 \\
Total & 100.09 \\
Analyzed Nutrient Composition (\%) & \\
Dry Matter & 91.23 \\
Crude Protein & 18.00 \\
Ether Extract & 4.95 \\
Crude Fibre & 11.00 \\
Ash & 9.55 \\
NFE & 47.03 \\
DE(Kcal/kg) & 2740.48 \\
Dry Matter & 91.23 \\
\hline
\end{tabular}

Each $1 \mathrm{~kg}$ of vitamin/mineral premix manufactured by BEAUTS Co. Inc. Man, U.S.A, contains Vitamin A 220,000, Vitamin D 66,000, Vitamin E 44, 014; Vitamin K $88 \mathrm{mg}$; Vitamin B 12; $0.76 \mathrm{mg}$; Niacin $1122 \mathrm{mg}$, Calcium $27 \%$, Phosphorus $10 \%$, Iron $0.6 \%$, Zinc $0.35 \%$, manganese $0.25 \%$, Copper $0.06 \%$; Iodine $0.002 \%$, Cobalt $26 \mathrm{ppm}$, Selenium $4 \mathrm{pp} . \mathrm{ME}=$ Metabolizable Energy.

\subsection{Management of Experimental Animals and Design}

Thirty mixed breed (California, chinchilla, New Zealand) weaned rabbits with average weight of $365.00 \mathrm{~g}$ and of both sexes were used for the experiment. The rabbits were obtained from a local farmer in Makurdi. The rabbits on arrival were allowed a preliminary feeding period of seven days for acclimatization. They were then weighed and randomly allocated to treatments. The rabbits were assigned to five dietary treatments with six replicates each in a Completely Randomized Design (CRD). Each rabbit in a treatment serve as a replicate and were housed individually in wire mesh hutches measuring about $60 \times 40 \times 40 \mathrm{~cm}$ containing a feeder and a drinker. The rabbits were fed on their various experimental diets daily for 12 weeks. Each rabbit was inspected daily for good health. Prophylactic medication was administered against pathogens infection. Standard health and sanitation procedures were strictly observed during the experimental period.

\subsection{Chemical Analysis}

The proximate analyses of Ficcus thoningii, Vitex doniania, Daniela olveri, Sarcocephatus latifolia and experimental diet 
were carried out according to AOAC [4].

\subsection{Anti-nutritional Factors of the Browse Plants Leaves}

Phytate in the leaves was estimated as phytic acid using the method of [27] and by titration method described by Wheeler and Ferrei [45]. Saponins was determined gravimetrically by the method of [41] as reported by [5]. Oxalate was determined titrimetrically as described by Chinma and Igyor [14], Tannin was determined using the methods described by [9]. Alkaloid was determined by the method described by Harbone [20].

\subsection{Blood Parameters}

At the end of the feeding trial, three (3) rabbits per treatment were selected for the evaluation of haematological indices and serum biochemical variables. Two (2) milliliters (ml) of blood sample was collected from the external jugular veins of the rabbits by vein puncture using $5 \mathrm{ml}$ disposable needles into a labeled sterile bottle containing ethylene diaminetetra acetic acid (EDTA) an anticoagulant, $1 \mathrm{ml}$ of the powder for $1 \mathrm{ml}$ of blood was used. The collection sites were sterilized with $70 \%$ alcohol and Zylene applied to dilate the veins. Haematological indices analyzed include Red Blood Cell count (RBC), White Blood Cell count (WBC), Haemoglobin concentration (Hb), Packed Cell Volume (PCV) and Mean Corpuscular Volume (MCV).

The improved Nuebaer Haemocytometer method described by Jain [23] was used to estimate the red and white blood cells, haemoglobin method according to [25]. Packed Cell Volume (PCV) was determined by using Wintrobs Microhaematocrit method [15], the determination of the distribution of the various blood cells was done by Shilling method of differential leucocyte counts [30], and Mean Corpuscular Haemoglobin (MCH) and Mean Corpuscular Haemoglobin Concentration (MCHC) were computed according to Jain [23].

A second set of tubes free of anticoagulant was used to collect blood samples for Serum biochemical analysis. The blood was allowed to clot to obtain Serum by allowing the blood sample to stand for 2 hours at room temperature, and centrifuged using the High Speed Wintrobes Microhaematocrit for 10 minutes at $2000 \mathrm{rpm}$ to separate the cells from the serum. Serum is preferred for estimation of biochemical substances because many of these substances are present in difference concentrations in the serum and the $\mathrm{RBC}$ and it is the concentration in the serum which changes in disease or abnormal conditions, and therefore aids in diagnosis [40]

Serum protein, globulin and urea were analyzed using Sigma Kids, glucose was analyzed according to [38] and cholesterol according to [40]

\subsection{Statistical Analysis}

All data obtained were subjected to Analysis of Variance (ANOVA) using [29].

\section{Results and Discussion}

\subsection{Proximate Composition of Experimental Browse Plants Leaves}

The proximate composition of experimental browse plant leaves is shown in table 2 . The range of crude protein of 8.75 to $18 \%$ reported of the browse plant use in the experiment was within the range of 5.00 to $35.00 \%$ reported by [11] for tropical browse plant leaves and is also within the range reported by [42] of 7.00 to $28 \%$ for most browse plant leaves.

The CF range of 7.32 to 22.08 was a bit lower than the value 9.00 to $30.00 \%$ obtain by [11] and that reported by [42] of 9.0 to $37 \%$. The EE range of 2.00 to $6.41 \%$ present in experimental browse plant leaves was also within range $(1.5$ to $12.00 \%$ ) reported by [42]. These differences could be attributed to variations in location and varieties of browse plant leaves.

Table 2. Proximate composition of experimental browse plant leaves (\%).

\begin{tabular}{lllll}
\hline Parameters & $(\boldsymbol{F t})$ & $(\boldsymbol{V d})$ & $(\boldsymbol{D o})$ & $(\boldsymbol{S} \boldsymbol{)})$ \\
\hline Dry Matter & 92.28 & 93.21 & 92.52 & 90.22 \\
Crude protein & 17.47 & 13.10 & 8.70 & 8.75 \\
Ether Extract & 2.65 & 4.63 & 6.41 & 2.00 \\
Ash & 15.35 & 7.78 & 10.08 & 5.09 \\
Crude Fibre & 22.08 & 11.17 & 14.47 & 7.32 \\
Nitrogen Free Extract & 65.27 & 56.53 & 52.86 & 67.06 \\
DE (Kcal/kg) & 3180.25 & 2870.25 & 2722.77 & 2867.98 \\
\hline
\end{tabular}

$F t=$ Ficcus thoningii, $V d=$ Vitex doniana, Do = Daniela oliveri, $S l=$ Sarcocephalus latifolia, $\mathrm{DE}=$ Digestible Energy obtained using the formula recommended by Pauzenga Equation $(1985)$ i.e. $\mathrm{DE}=(37 \mathrm{x} \% \mathrm{CP})+(81.8$ $\mathrm{x} \% \mathrm{EE})+(35.5 \mathrm{x} \% \mathrm{NFE})$

\subsection{Anti-nutritional Factors of Experimental Browse Plants Leaves}

Anti-Nutritional factors of experimental browse plant leaves are shown in table 3 . The percentage components of anti-nutritional factors in this present study were low but comparable with the reports of [6], [28]. Among the antinutritional factors, the tannin content of 1.22, 2.34, 5.1 and 0.34 obtained in Ficcus thoningii, Vitex doniana, Daniela oliveri, and Sarcocephalus latifolia respectively were comparable to values $(0.13$ to $6.31 \%)$ reported previously by [19]. A threshold concentration of $5 \%$ tannin had been reported above which there is rejection of browse plant leaves by goats [36].

The phytin levels reported in this study ranged from 0.42 to $4.02 \mathrm{~mm} / 100 \mathrm{~g}$, which is lower than the 13.80 to $25.20 \mathrm{~mm} / 100 \mathrm{~g}$ reported by [35] for the southeastern browses in Nigeria. These levels are unlikely to have any adverse effects on animals. A threshold concentration of 15.90 $30.50 \mathrm{~mm} / 100 \mathrm{~g}$ has been reported for rabbit.

The oxalate content of the browse species was not consistent with the reported values (1.49 to 5.79\%) of some browse plants relished by ruminants in Nigeria [17]. Oxalate content in this present study was low. It has been reported that $20 \mathrm{~g} / \mathrm{kg}$ oxalate can be lethal to chicken [1]. A threshold concentration of $25-30 \mathrm{~g} / \mathrm{kg}$ may not be harmful ruminant 
and pseudo-ruminant.

The saponin content of $0.002-2.55 \mathrm{~mm} / 100 \mathrm{~g}$ was also low as in other leguminous browse species. Oduguwa et al. [33] reported values of $3.24 \%$ and $3.47 \%$ for Parkia biglobosa and Afzelia africana respectively. Feedstuffs containing saponin had been shown to be defaunting agents [44]. Cheeke [10] reported that saponin has effect on erythrocyte haemolysis, reduction of blood and liver cholesterol, depression of growth rate, bloat (ruminant) inhibition of smooth muscle activity, enzyme inhibition and reduction in nutrient absorption. Saponins have been reported to alter cell wall permeability and therefore produce some toxic effect when ingested [7]. The anti-nutritional effects of saponins have been mainly studied using alfalfa saponins. Sharma and Chandra [41] observed that 4-7 weeks of ad libitum feeding of albizia gave rise to toxic manifestation in sheep. Symptoms include listlessness, anorexia, weight loss and gastro-enteritis. Though the level of saponin recorded in this present study may not pose any problem to the animals. A threshold concentration of $0.004-5.65 \mathrm{~mm} / 100 \mathrm{~g}$ has been reported by [7].

Table 3. Anti-Nutritional factors of experimental browse plant leaves.

\begin{tabular}{lllll}
\hline Anti-nutrient (mm/100g) & $(\boldsymbol{F t})$ & $(\boldsymbol{V d})$ & $(\boldsymbol{D o})$ & $(\boldsymbol{S l})$ \\
\hline Tannin & 1.22 & 2.34 & 5.1 & 0.34 \\
Phytate & 4.02 & 0.18 & - & 0.42 \\
Oxalate & 12.3 & 0.39 & - & - \\
Saponins & 3.60 & - & 0.002 & 1.25 \\
Alkaloids & - & 0.89 & 0.001 & 2.38 \\
\hline
\end{tabular}

$\mathrm{Ft}=$ Ficcus thoningii, Vd $=$ Vitex doniana, Do $=$ Daniela oliveri, $\mathrm{Sl}=$ Sarcocephalus latifolia, $(-)=$ not present

\subsection{Haematological Indices of Rabbits Fed Concentrate Diet and some Evergreen Tropical Browse Plant Leaves}

Haematological indices of rabbits fed concentrate diets and some evergreen tropical browse plants leaves are presented in table 4 . The RBC values of 4.57 to $5.67 \times 106 \mu$ l obtained in this study was within the normal reference values of 3.7 to
$7.5 \times 106 \mu 1$, reported by [21]. This may be an indication that the browse plant leaves did not have some detrimental effect on the RBC of the rabbits. The WBC of T 4 and T 5 (4.80 and $5.10 \times 103 \mu \mathrm{l})$ respectively were below the normal reference range of 5.2 to $16.5 \times 103 \mu 1$ [21] for normal rabbits, this may be an indication that the Daniela oliveri and Sarcocephalus latifolia in the diet suppress haemopoietic tissue, hence inadequate WBC were produced [34]. However, the effect of inadequate WBC did not occur in T 4 and $\mathrm{T} 5$ as the rabbits were healthy throughout the experimental period and no mortality was recorded. The WBC of T 1, T 2 and T 3 $(7.07,6.43$ and $6.73 \times 103 \mu \mathrm{l})$ respectively were within the normal reference range of 5.2 to $16.5 \times 103 \mu 1$ [34] for normal rabbits, this may be an indication that adequate $\mathrm{WBC}$ was produced as the rabbits were healthy throughout the experimental period.

Haemoglobin values of 12.00 to $12.97 \mathrm{~g} / \mathrm{dl}$ were recorded in this study and were within range of 11 to $14.5 \mathrm{~g} / \mathrm{dl}$ reported by [43] for normal rabbits. This may be suggested that, the utilization of the experimental browse plant leaves in rabbit diet did not impair nutrient availability in the diet such that would cause anaemic condition and that protein intake was adequate. The PCV values of $36.00-39.00 \%$ obtained in this study are within the normal range of $26.7-47.2 \%$ reported by [34] for normal rabbits. It thus means that, the nutritional adequacy of the diet was maintained by all the browse plant leaves used.

The MCV values obtained in this study for $\mathrm{T} 1, \mathrm{~T} 2, \mathrm{~T} 3$ and $\mathrm{T} 5$ (71.73, 68.40, 72.43 and $65.03 \times 1015 / \mathrm{fl}$ respectively) were observed to be within the normal reference range of (58.0 to $76 \times 1015 / \mathrm{fl})$ reported by [34] for normal rabbits. While MCV value of T $4(81.40 \times 1015 / \mathrm{fl})$ was observed to be higher than the normal reference range of 58.0 to $76 \times 1015 / \mathrm{fl}$. [26] reported that reduction or abnormal values of Haematology indices may indicate a low protein intake, liver damage, anaemia or parasitological infestation. This however did not apply to the rabbits in $\mathrm{T} 4$ as the animals were not seen with any of these abnormalities.

Table 4. Haematological indices of rabbits fed concentrate diet and some evergreen tropical browse plant leaves.

\begin{tabular}{|c|c|c|c|c|c|c|c|c|}
\hline Parameters & $T_{1}$ (control) & $\mathrm{T}_{2}(F t)$ & $\mathrm{T}_{3}(V d)$ & $\mathrm{T}_{4}(\mathrm{Do})$ & $\mathrm{T}_{5}(\mathrm{So})$ & NRV & SEM & P value \\
\hline$(\mathrm{RBC}) \times 10^{6} / \mu \mathrm{l}$ & 5.20 & 5.23 & 5.27 & 4.57 & 5.63 & $3.70-7.50$ & 0.39 & 0.596 \\
\hline$(\mathrm{WBC}) \times 10^{3} / \mu 1$ & 7.07 & 6.43 & 6.73 & 4.80 & 5.10 & $5.20-16.5$ & 0.72 & 0.278 \\
\hline$(\mathrm{Hb}) \mathrm{g} / \mathrm{dl}$ & 12.43 & 12.53 & 12.97 & 12.77 & 12.00 & $11.6-14.5$ & 0.68 & 0.923 \\
\hline$(\mathrm{PCV}) \%$ & 37.33 & 37.67 & 39.00 & 38.33 & 36.00 & $26.7-47.2$ & 2.06 & 0.918 \\
\hline$(\mathrm{MCV}) \times 10^{15} / \mathrm{fl}$ & $71.73^{\mathrm{ab}}$ & $68.40^{\mathrm{ab}}$ & $72.43^{\mathrm{ab}}$ & $81.40^{\mathrm{a}}$ & $65.03^{\mathrm{b}}$ & $58.0-76.6$ & $3.91 *$ & 0.198 \\
\hline
\end{tabular}

$F t=$ Ficcus thoningii, $V d=$ Vitex doniana, Do = Daniela oliveri, Sl = Sarcocephalus latifolia, ${ }^{\text {abc }}$ Mean on the same row with different superscripts are significantly different $(\mathrm{p}<0.05), \mathrm{SEM}=$ Standard Error of Mean, $*=$ Significant difference $(\mathrm{p}<0.05)$, NRV $=$ Normal Reference Value, RBC $=$ Red blood cell count, $\mathrm{WBC}=$ White blood cell count, $\mathrm{Hb}=$ Haemoglobin concentration, $\mathrm{PCV}=$ Packed Cell Volume, MCV $=$ Mean Corpuscular Volume.

\subsection{Serum Biochemical Variable of Rabbits Fed Concentrate Diet and some Evergreen Tropical Browse Plant Leaves}

Serum biochemical variable of rabbits fed concentrate diets and some evergreen tropical browse plants leaves is presented in table 5 . The total protein in this study varied from $4.17 \mathrm{~g} / \mathrm{dl}$ to $6.37 \mathrm{~g} / \mathrm{d}$ and it is not in agreement with the normal reference value (5.3 to $6.0 \mathrm{~g} / \mathrm{dl})$ reported by [43] for rabbits, except for rabbits in $\mathrm{T}_{5}$ which had a value of 5.60 $\mathrm{g} / \mathrm{dl}$ that was in agreement with the normal reference value. However, rabbits in $\mathrm{T}_{1}, \mathrm{~T}_{2}, \mathrm{~T}_{3}$ and $\mathrm{T}_{4}$ diet had abnormal values from the range, this may imply that the rabbits were under thermal stress thus there was deviation in total serum 
protein. Kaneko [24] reported that thermal stress causes an increase in adrenal activity resulting in increase or decrease turnover which leads to changes in total serum protein. Sarcocephalus latifolia must have helped in the reduction of internal thermal stress which helped in osmotic balance between the circulatory blood and tissues space [24]. Total protein concentration is a measure of the quality of the diet consumed by livestock. Thus from the performance of the rabbits it can be inferred that the various experimental diet contained adequate nutrients for the healthy growth of growing rabbits.

The globulin values obtained ranged from 2.37 to $5.20 \mathrm{~g} / \mathrm{dl}$. The serum globulin value of the control group was $2.37 \mathrm{~g} / \mathrm{dl}$ and it was in line with the globulin values for rabbits fed the browse plant leaves diet. This may be an indication that the browse plant leaves as diet did not adversely affect the nutritional status of the experimental animal.

The serum urea nitrogen of $41.60 \mathrm{mg} / \mathrm{dl}$ for $\mathrm{T}_{4}$ in this study is higher than the normal reference values of 30.0 to 37.3 $\mathrm{mg} / \mathrm{dl}$ [30], except for $\mathrm{T}_{1}, \mathrm{~T}_{2}, \mathrm{~T}_{3}$ and $\mathrm{T}_{5}$ that were within the reference value of [30]. The values obtained in $\mathrm{T}_{4}$ was lower than the reference values of 45.7 to $68.9 \mathrm{mg} / \mathrm{dl}$ [43] and 81 $250 \mathrm{mg} / \mathrm{dl}$ [21]. Abnormal level of serum urea is an indication of the quality of protein fed. Urea is a function of protein quality, and high urea indicates low protein quality fed [16]. Since urea was highest in $\mathrm{T}_{4}$, it may be suggested that Daniela oliveri increased the level of urea in rabbit diet.

Table 5. Serum biochemical variables of rabbits fed concentrate diet and some evergreen tropical browse plant leaves.

\begin{tabular}{|c|c|c|c|c|c|c|c|c|}
\hline Parameters & $\mathrm{T}_{1}$ (control) & $\mathrm{T}_{2}(F t)$ & $\mathrm{T}_{3}(V d)$ & $\mathrm{T}_{4}(\mathrm{Do})$ & $\mathrm{T}_{5}(\mathrm{So})$ & NRV & SEM & P value \\
\hline Total Protein $(\mathrm{g} / \mathrm{dl})$ & $4.90^{\mathrm{ab}}$ & $4.97^{\mathrm{ab}}$ & $6.37^{\mathrm{a}}$ & $4.17^{\mathrm{b}}$ & $5.60^{\mathrm{ab}}$ & $5.30-6.00$ & $0.60 *$ & 0.296 \\
\hline Globulin (mg/dl) & 2.37 & 5.20 & 4.17 & 2.63 & 2.40 & - & 1.21 & 0.538 \\
\hline Urea $(\mathrm{mg} / \mathrm{dl})$ & 34.83 & 37.67 & 35.20 & 41.60 & 36.37 & $30.0-37.30$ & 3.16 & 0.698 \\
\hline Glucose (mg/dl) & $77.6^{\mathrm{c}}$ & $82.93^{\mathrm{bc}}$ & $92.93^{\mathrm{ab}}$ & $100.1^{\mathrm{a}}$ & $98.03^{\mathrm{a}}$ & $65.3-74.80$ & $2.76^{*}$ & 0.002 \\
\hline Cholesterol (mg/dl) & 64.67 & 60.67 & 72.33 & 51.30 & 59.07 & $77.9-134.4$ & 8.47 & 0.651 \\
\hline Albumin (mg/dl) & 3.57 & 3.13 & 3.33 & 3.67 & 4.10 & $2.40-6.10$ & 0.45 & 0.735 \\
\hline
\end{tabular}

$F t=$ Ficcus thoningii, $V d=$ Vitex doniana, Do = Daniela oliveri, Sl = Sarcocephalus latifolia, ${ }^{\text {abc }}$ Mean on the same row with different superscripts are significantly different $(\mathrm{p}<0.05), \mathrm{SEM}=$ Standard Error of Mean, $*=$ Significant difference $(\mathrm{p}<0.05)$, NRV $=$ Normal Reference range.

Glucose levels of 77.60 to $100.10 \mathrm{mg} / \mathrm{dl}$ in this study are higher than 65.3 to $74.8 \mathrm{mg} / \mathrm{dl}$ reported by [30], and 63.83 to $82.93 \mathrm{mg} / \mathrm{dl}$ reported by [32]. This showed a tendency towards hyperglycaemic condition, hyperglycaemia implies high blood glucose levels which in extreme cases results to death. High blood glucose levels in rabbit could also occur due to little insulin production and disturbance in digestion [30]. The abnormal range of serum glucose level obtained for rabbits in this study indicate that, the rabbits were probably suffering from disturbance in digestion due to low environmental temperature as at the time of the experiment (April to July).

The serum cholesterol obtained varied from 51.30 to 72.33 $\mathrm{mg} / \mathrm{dl}$, and were below normal reference values of 77.9 to $134.4 \mathrm{mg} / \mathrm{dl}$ [43]. The experimental rabbits were not vulnerable to coronary condition which may result to ill health when the serum cholesterol is low, since values obtained were below the normal reference value. The serum albumin values of 3.13 to $4.10 \mathrm{mg} / \mathrm{dl}$ obtained in this study are also within the normal range of 2.4 to $6.1 \mathrm{~g} / \mathrm{dl}$ [43]. Thus, the various browse plant leaves as diet did not adversely affect the nutrient quality of the experimental diet.

\section{Conclusion}

1) The proximate composition of experimental forages of the test ingredient revealed that the forages did not interfere with nutrient and chemical absorption by rabbits since most of its anti-nutritional factors were in very low amount.

2) The values of haematology and serum biochemistry were comparable with the normal reference values, an indication of nutritional adequacy and safety of the browse plant leaves. The rabbits were able to meet their nutrient requirements for tissue accretion.

\section{References}

[1] Acamovic, T, Steward, C. S. and Pennycott, T. W. (eds) (2004). Poisons plants and related toxins. Oxford University Press, 608pp.

[2] Akinmutimi, A. H. and Osuagwu, C. C. (2008). Response of Weaner Rabbits Fed Graded Levels of Sweet Potato Meal in Place of Maize-Based Diet. Pakistan Journal of Nutrition 7 (5): 705-709.

[3] Amata, I. A. and Lebari, T. A. (2011). Comparative evaluation of the nutrient profile of four selected browse plants in the tropics, recommended for use as non-conventional livestock feeding materials. African Journal of Biotechnology 10 (64): 14230-14233.

[4] A. O. A. C. (1980). Association of Official Analytical Chemist. 15th Ed. William Tryd Press, Richard Virginia, USA pp 1018.

[5] Babayemi, O. J, Demeyer, D. and Fervez, V. (2004). Nutrition Value of quantitative assessment of secondary compounds in seeds of eight tropical browse, shrub and pulse legumes comm. Appl Biol. Sci. Glent University, 69/1:103-110.

[6] Bamikole, M. A, Ikhatua, U. J, Arigbede, O. M, Babayemi O. J, Etela I. (2004). An evaluation of the acceptability as forage of some nutritive and anti-nutritive components and of the dry matter degradation profiles of five species of ficus. Tropical Animal Health and Production. 36:157-167. 
[7] Belmar, R, Nava-Montero, R, Sandoval- Castro, C. and Menab, J. M. (1999). Jackbean (canuvalia ensiforms L. DC) in poultry diets: Anti-nutritional factors and detoxification studies. A. Review. Poultry Sci. J. 55 (1) 37-59.

[8] Biobaku, W. O. (1994). Effects of feeding raw and cooked delonix ragia seed bean on the performance of rabbits. Journal of Agricultural Technology 7: 10- 14.

[9] Bohm, A. B. and Kocipai, A. A. (1994). Flavonoids and condensed Tannis from leaves of Hawaiian Vaccinium vaticulation and $V$. calycinnium, pacific science, 48,458-453.

[10] Cheeke, P. R. (1971). Nutritional and Physiological implication Saponins: A Review. Canadian J. Ani. Sci. 51: 621-623.

[11] Cheeke, P. R. and Shull, L. R. (1984). Natural Toxicants in feeds and livestock. AVI publishing INC, West port, Connecticut.

[12] Cheeke, P. R, (1986). Potential of rabbit production in tropical and subtropical agricultural systems. Journal of Animal Science 63: 1581- 1586.

[13] Cheeke, P. R. (1992). Feeding systems for tropical rabbit production emphasizing roots, tubers and bananas in: Roots, tubers, plantains and bananas in animal feeding. Proceedings of the FAO Expert Consultation, held in CIAT, Cali, Colombia, 21st-25th January, 1991.

[14] Chinma, C. E. and Igyor, M. A. (2007). Micronutrient and ante-nutritional contents of selected tropical vegetable grown in southeast Nigeria, Nigeria food Journal 25(1):111-116.

[15] Dacie, J. V. and Lewis, S. M. (1991). Practical Heamatology. 7th Edition, Livinton, (ELBS) Church Hill Publishers.

[16] Eggum, B. O. (1970). Blood urea measurement as a technique for assessing protein quality, Brit. J. Nutr. 24: 983-988.

[17] Fadiyimu, A. A, Fajemisin, A. N, Alokan, J. A. (2011). Chemical composition of selected browse plants and their acceptability by West African dwarf sheep. Livestock for Rural Development: 23 (12).

[18] George (2003). The potentials of local vegetables in Nigeria. Hand book on Agriculture 2 (3). 80-86.

[19] Gidado, O. G, Kibon, A, Gwargwor, Z. A, Mbaya, P, Baba, M. J. (2013). Assessment of antinutrient factors and nutrient composition of some selected browse plants use as livestock feeds in Taraba state. International Journal of Applied Science and Engineering:1(1): 5-9.ion.

[20] Harbone, Z. B. (1973). Phytochemical methods A guide to modern techniques of plant analysis. Chapman and Hall, London. pp. 113-185

[21] Hewitt, C. D, Innes, D. J. Savory, J. And Wills, M. R. (1989). Normal Biochemical and hematological values in New Zealand white rabbits Clin. Chem. 35 (8): 1777-1779.

[22] Iloeje, N. P. (1991). New Geography of Nigeria, new revised edition. Academic press limited Lagos, pp 23: 44-74.

[23] Jain, C. N. (1986). Schalms veterinary Haematology. 4th Edition, Philadelphia. Lea and Febiger Publishers.

[24] Kaneko, J. J. (1989). Clinical Biochemcial of Domestic Animals, 4th Edition, London academy Press Ltd. Pp 495-498.
[25] Kelly, W. R. (1979). Veterinary Clinical Diagnosis. 2nd Edition, London, Bailliere Tindall Publishers.

[26] Lindsay, D. B. (1977). The effect of feeding patterns and sampling of blood parameters. Brit. J. Nutr. 56:99-120.

[27] Maga, J. A. (1982). Phytete, its chemistry, occurrence, food interaction, Nutritional significant methods of analysis. Journal of Agriculture food and Chemistry, volume 30, pp. 1-5.

[28] Mbomi, S. E, Ogungbesan, A. M, Babayemi, O. J, Nchinda, N. P. (2011). Chemical composition, acceptability of three Tephrosia species and use of Tephrosia purprerea as supplement for grazing animals in the western highlands of Cameroon. Journal of Environmental Issues and Agriculture in Developing Countries: 3(3):132-138.

[29] MINITAB Statistical Software (2014). V.16, Minitab Inc. P. A, US.

[30] Mitruka, B. M. and Rawnsley, H. (1977). Clinical Biochemistry and Heamatologycal Reference values in National Experimental Animals.1st Edition, New York, USA. Masson Publishing Inc. PP. 106-112.

[31] Nemeat Meteological Agency (2014). Bebi Airstrip, Obanliku, Cross River State.

[32] Ochefu, J. (2006). The effect of Kapok (Ceiba pentandra) seed meal based diets on growth carcass yield and blood chemistry of weaner rabbits. M. Sc. Thesis, Department of Animal Breeding and Physiology, University of Agriculture. Makurdi.

[33] Oduguwa, O. O, Oduguwa, B. O, Onwuka, C. F. I, Olajobi, H. O. (1998). Anti-nutritional factors in foliage of some leguminous trees and shrubs. In: O Oduguwa, A O Fanimo, OA Osinowo (eds). Animal agriculture in West Africa. The Sustainability Question. Proceedings of the Silver Jubilee Anniversary Conference of the Nigerian Society for Animal Production; 339-340.

[34] Ojebiyi, O. O, Farinu, G. O, Tongun, V. A, Akinlade, J. A, Aderinola, O. A. Olayeni, T. B. and Moronfalu, O. O. (2007). Studies on growth and haematological attributes of weaned rabbits fed graded levels of sun-dried cassava peel blood meal mixture, 32nd Ann. Conf. Nig. Soc.

[35] Okoli, I. C, Maureen, O, Anunobi, O, Obua, B. E. and Enemuo, V. (2003). Studies on selected browses of southeastern Nigeria with particular reference to their proximate and some endogenous anti-nutritional constituents. Livestock Res. Rural Dev. 15 (9): 3-7.

[36] Ologhobo A. (1989). Mineral and anti-nutritional contents of forage and legumes consumed by goats in Nigeria. In: RT Wilson, A Melaku (Eds). Proceedings of a Conference on African Small Ruminant Research and Development, Bamenda, Cameroon.

[37] Pauzenga, U. (1985). Feeding parent-stock. Zootecncia International, December 1985, pp: 22-24.

[38] Powell, J. B. and Djuh, Y. Y. (1971). A comparison of automated methods for glucose analysis in patients with uremia before and after dialysis. Am. J. Clin. Pathol. 56, 8-16.

[39] Rajesdevan, P, Goonewardema, L. and Ravindran, R. S. B. (1987). An investigation on the reproductive traits of crossbred rabbits in Seri Lanka World. Review Animal production. 23(2): 91-95. 
[40] Roschlan, P, Bernet, E. and Grubner, W. (1974). Veterinary Clinical Pathology. 2nd Edition, Philadelphia. W. B. Saunders Company. Pp.403-407.

[41] Sharma, D. D. S. and Chandra, S. S. (2001). The nutritive value and toxicity of OHI (Albizia stipulate Bovin) tree leaves. J. Res. Ludlhiana 6: 388-393.

[42] Shane G. (2012). Composition of some Livestock Feeds. University of Arkansas Cooperative Extension Service Printing Services.
[43] Talis De, O. S, Luiz, C. K, Leonado, J, Joao, B, Auren, B. S. and Cleverson, S. (2005). Reference values for Chinchilla (Chinchilla laniger) Blood cells and serum biochemical parameters. Cienc. Rural.35 (3):1-8.

[44] Teferedegne, B. (2000). New perspectives on the use of tropical plants to improve ruminant nutrition. Pro. Nutr. Soc, 59: 209-214.

[45] Wheeler, E. L. and Ferrei, R. E. (1971). A method for phytate acid determination in wheat and wheat fractions. Cereal chemistry, 48:312-320. 